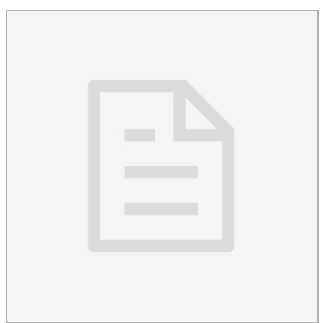

MAY 20, 2020

\section{OPEN OCCESS}

Dol:

dx.doi.org/10.17504/protoco s. io. bgdkjs 4 w

\section{External link:}

https://www.machado.cnptia. embrapa.br/plantannot

Protocol Citation: Marcos Viana, Mauricio Mudadu, Adhemar Zerlotini 2020. Find Proteins of Unknown Function (PUFs) using Plantannot Protocol F. protocols.io https://dx.doi.org/10.17504/p rotocols.io.bgdkjs $4 \mathrm{w}$

License: This is an open access protocol distributed under the terms of

the Creative Commons Attribution License, which permits unrestricted use, distribution, and reproduction in any medium, provided the original author and source are credited

\section{Protocol status: Working}

It is working

Created: May 14, 2020

Last Modified: May 20, 2020

PROTOCOL integer ID: 37004
B Find Proteins of Unknown Function (PUFs) using Plantannot - Protocol $F$

PForked from Find Proteins of Unknown Function (PUFs) using Plantannot - Protocol E

Marcos Viana ${ }^{1}, \quad$ Mauricio Mudadu ${ }^{1}$, Adhemar Zerlotini $^{1}$

${ }^{1}$ EMBRAPA

Marcos Viana

\section{ABSTRACT}

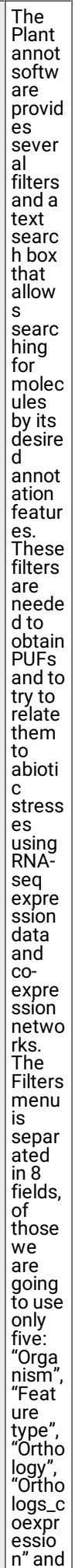




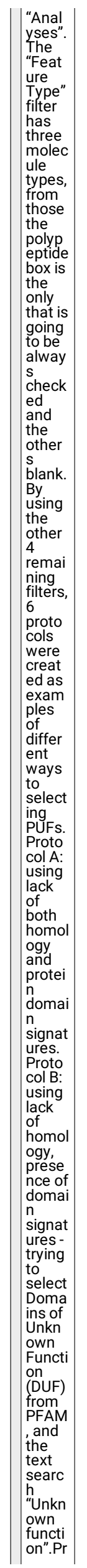




\begin{tabular}{|l|}
\hline Proto \\
col F \\
is \\
intend \\
ed to \\
find \\
PUFs \\
from \\
organi \\
sms \\
that \\
protei \\
ns are \\
alread \\
y \\
public \\
in the \\
NCBI \\
s "nr" \\
datab \\
ase \\
and \\
have \\
no \\
protei \\
n \\
domai \\
n \\
found \\
by \\
Interp \\
rosca \\
n. \\
Protei \\
ns will \\
be \\
select \\
ed \\
using \\
the \\
text \\
searc \\
h \\
"Unkn \\
own \\
functi \\
on". \\
Also, \\
orthol \\
og \\
group \\
s and \\
co- \\
expre \\
ssion \\
netwo \\
rks \\
will be \\
used \\
to \\
relate \\
protei \\
ns to \\
abioti \\
c \\
stress \\
es. \\
\hline
\end{tabular}

\section{Entering application}

1 Enter the Plantannot Result's page, with empty filters and text box search: https://www.machado.cnptia.embrapa.br/plantannot/find/?q=

Or you can enter the https://www.machado.cnptia.embrapa.br/plantannot initial page and click on the magnifying glass with the text box empty as well.

\section{Plant Co-expression Annotation Resource Data summary About}

\section{Embrapa}

https://www.machado.cnptia.embrapa.br/plantannot

\section{Filtering}

2

Find PUFs from organisms that proteins are already public in the NCBI's "nr" database and have no protein domain found by Interproscan. Proteins will be 
Visualize the "Filters" card on the left of the page from step1:

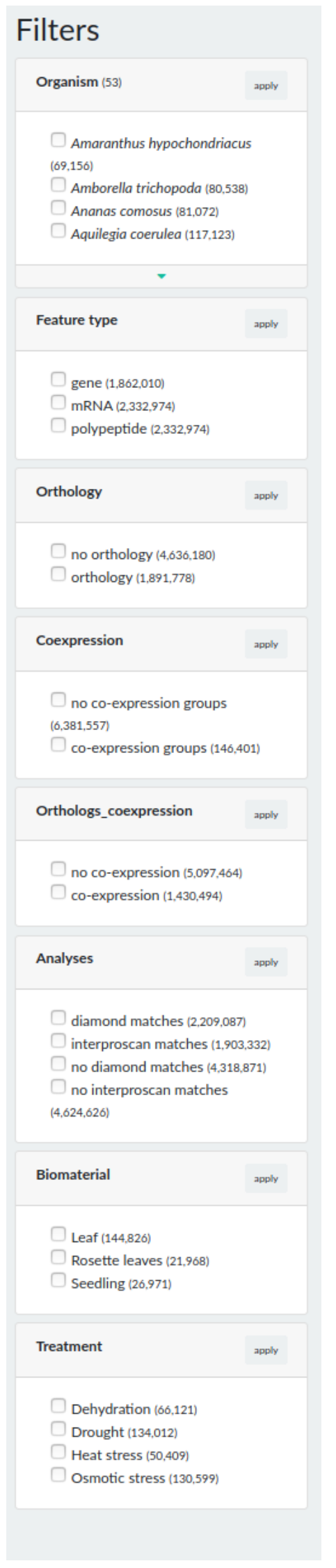


https://www.machado.cnptia.embrapa.br/plantannot/find/?q=

2.1 In the "Organisms" filter, select any organisms (expand the organism's list using the green arrow) or select all by leaving all boxes empty. We will use Oropetium tomaeum as example. Click "apply" to execute the filter:

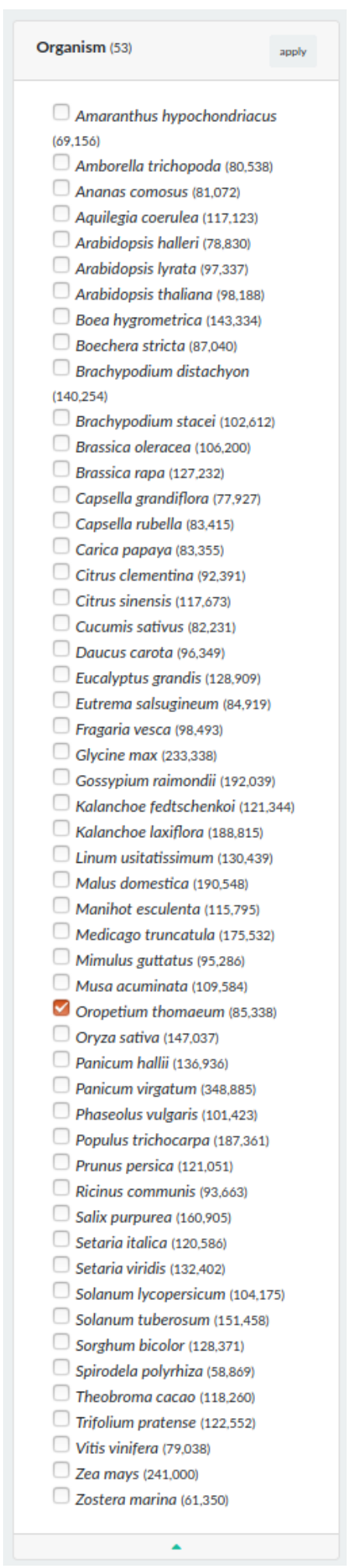

https://www.machado.cnptia.embrapa.br/plantannot/find/?q=\&selected_facets=organism\%3AOropetium+thomaeum 


\begin{tabular}{|c|c|}
\hline Feature type & apply remove \\
\hline $\begin{array}{l}\square \text { gene (0) } \\
\square \text { mRNA (0) } \\
\square \text { polypeptide }(2,551)\end{array}$ & \\
\hline
\end{tabular}

https://www.machado.cnptia.embrapa.br/plantannot/find/?

$\mathrm{q}=\&$ selected_facets=organism\%3AOropetium+thomaeum\&selected_facets=so_term\%3Apolypeptide

2.3 In the Orthology filter, select "orthology", and click "apply" to execute the filter:

\begin{tabular}{|l|l|}
\hline Orthology & apply remove \\
\hline & $\square$ no orthology (0) \\
& $\square$ orthology $(18,755)$ \\
\hline
\end{tabular}

https://www.machado.cnptia.embrapa.br/plantannot/find/?

q=\&selected_facets=organism\%3AOropetium+thomaeum\&selected_facets=so_term\%3Apolypeptide\&selected_facets=orthology\%3A1

2.4 Leave the "Coexpression" filter empty:

\begin{tabular}{|l|}
\hline Coexpression \\
\hline \\
$\square$ no co-expression groups (711) \\
$\square$ co-expression groups (0) \\
\hline
\end{tabular}

2.5 In the "Orthologs_coexpression" filter, select "co-expression", and click "apply" to execute the filter:

\begin{tabular}{|l|l|}
\hline Orthologs_coexpression & apply remove \\
\hline & $\square$ no co-expression (0) \\
& $\square$ co-expression $(15,641)$ \\
\hline
\end{tabular}

https://www.machado.cnptia.embrapa.br/plantannot/find/?

$\mathrm{q}=\&$ selected_facets=organism\%3AOropetium+thomaeum\&selected_facets=so_term\%3Apolypeptide\&selected_facets=orthology\%3A1\&selected_facets=ort hologs_coexpression\%3Atrue

2.6 In addition to the applied filters, text search for "Unknown function" in the search box. After entering the text click on the magnifying glass icon to apply the search. 


\begin{tabular}{|l|l|}
\hline Analyses & apply remove \\
& $\square$ diamond matches (894) \\
& $\square$ interproscan matches (0) \\
& $\square$ no diamond matches (0) \\
& $\square$ no interproscan matches (894) \\
\end{tabular}

https://www.machado.cnptia.embrapa.br/plantannot/find/?

$\mathrm{q}=\&$ selected_facets=organism\%3AOropetium+thomaeum\&selected_facets=so_term\%3Apolypeptide\&selected_facets=orthology\%3A1\&selected_facets=ort hologs_coexpression\%3Atrue\&selected_facets=analyses\%3Adiamond+matches\&selected_facets=analyses\%3Ano+interproscan+matches

2.7 Leave the "Biomaterial" and "Treatment" filters empty:

\begin{tabular}{|l|}
\hline Biomaterial \\
\hline \\
$\square$ Leaf (0) \\
\hline Rosette leaves (0) \\
\hline Seedling (0) \\
\hline Treatment \\
\hline Dehydration (0) \\
$\square$ Drought (0) \\
$\square$ Heat stress (0) \\
$\square$ Osmotic stress (0) \\
\hline
\end{tabular}

2.8 In addition to the applied filters, text search for "Unknown function" using the search box. After entering the text click on the magnifying glass icon.

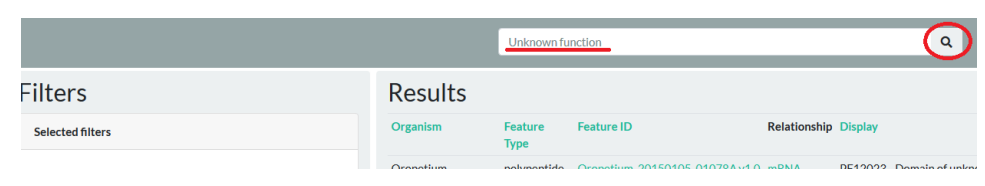

https://www.machado.cnptia.embrapa.br/plantannot/find/?

q=Unknown+function\&selected_facets=organism\%3AOropetium+thomaeum\&selected_facets=so_term\%3Apolypeptide\&selected_facets=orthology \%3A1\&s elected_facets=orthologs_coexpression\%3Atrue\&selected_facets=analyses\%3Adiamond+matches\&selected_facets=analyses\%3Ano+interproscan+matche $\underline{s}$

\section{Filters}

3 After execution of all filters we will have the following list of filters: 


\section{Selected filters}

search:Unknown function $\mathbf{X}$

organism:Oropetium thomaeum $\mathbf{X}$

so_term:polypeptide $\mathbf{X}$

orthology $\mathbf{X}$

coexpression in orthologs $\mathbf{X}$

analyses:diamond matches $\mathbf{X}$

analyses:no interproscan matches $\mathbf{X}$

https://www.machado.cnptia.embrapa.br/plantannot/find/?

q=Unknown+function\&selected_facets=organism\%3AOropetium+thomaeum\&selected_facets=so_term\%3Apolypeptide\&selected_facets=orthology\%3A1\&sele cted_facets=orthologs_coexpression\%3Atrue\&selected_facets=analyses\%3Adiamond+matches\&selected_facets=analyses\%3Ano+interproscan+matches

\section{Viewing results}

$4 \quad$ Visualize the "Results" card on the center-right of the screen. There will be the resulting list of Oropetium's PUFs. 4 PUFs were filtered:

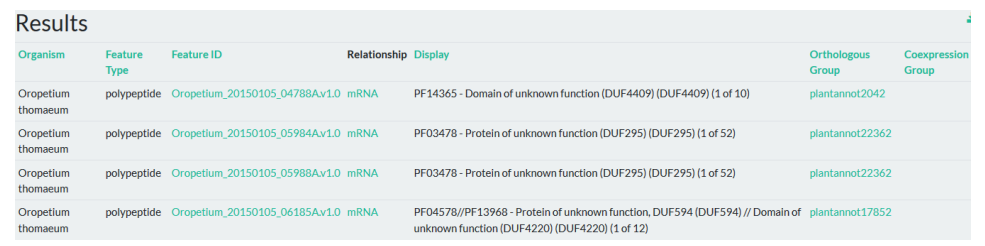

